\section{Decision-Making Quality of Public Managers: Contributions from Intelligence and Knowledge Management}

\author{
Qualidade Decisória dos Gestores Públicos: Contribuições da Inteligência e \\ Gestão do Conhecimento
}

\section{Claudia Melati ${ }^{1}$ \\ Raquel Janissek-Muniz ${ }^{10}$ \\ Carla Maria Marques Curado ${ }^{\circ}$}

\section{ABSTRACT}

Context: in recent years, studies have sought to analyze how intelligence and knowledge management processes are understood and applied in the context of public management, environments in which processes appear as a point to be explored to enhance decision-making quality. Objective: to analyze how public managers apply intelligence and knowledge management aiming at a higher decision quality. Method: based on a defined and validated research protocol, interviews were conducted with seventeen public managers in southern Brazil. For the analysis, the qualitative comparative analysis technique using fuzzy sets was applied. Results: the results suggest the importance of effective data, information, and knowledge management for the decision-making quality of public managers, demonstrating that the absence of decision-making quality is directly related to the absence or little use of knowledge management and intelligence elements in the public management. Conclusion: in addition to analyzing conditions and proposing ways to lead to greater quality in decision making by public managers, it was possible to contribute to the theme of knowledge management and intelligence in public management, as well as to benefit the government with paths to be consolidated and better explored.

Keywords: public management; knowledge management; intelligence; qualitative comparative analysis; fuzzy sets.
1. Universidade Federal de Rio Grande do Sul, Escola de Administração, Porto Alegre, RS, Brazil. 2. Universidade de Lisboa, Instituto Superior de Economia e Gestão, Lisboa, Portugal.

Cite as: Melati, C., Janissek-Muniz, R., \& Curado, C. M. M. (2021). Decision-making quality of public managers: Contributions from intelligence and knowledge management. Revista de Administração Contemporânea, 25(2), e190044. https://doi.org/10.1590/1982-7849rac2021 190044.en

\section{RESUMO}

Contexto: nos últimos anos, estudos buscaram analisar de que forma os processos de inteligência e de gestáo do conhecimento são compreendidos e aplicados no contexto da gestão pública, ambiente em que esses processos aparecem como um ponto a ser explorado para potencializar a qualidade decisória. Objetivo: analisar como os gestores públicos aplicam inteligência e gestão do conhecimento visando a uma maior qualidade decisória. Método: a partir de protocolo de pesquisa definido e validado, foram realizadas entrevistas com dezessete gestores públicos do sul do Brasil. Para a análise, foi aplicada a técnica de análise comparativa qualitativa utilizando conjuntos fuzzy para identificar caminhos efetivos para tomada de decisão em Governo. Resultados: os resultados indicam a importância da efetiva gestáo de dados, informaçóes e conhecimentos para qualidade decisória de gestores públicos, demonstrando que a pouca qualidade decisória está relacionada à ausência ou à reduzida utilizaçâo de gestão do conhecimento e inteligência na gestão pública. Conclusáo: além de analisar condiçóes e propor caminhos para levar a uma maior qualidade na tomada de decisão dos gestores públicos, foi possível contribuir para a temática de gestão do conhecimento e inteligência na gestão pública, bem como beneficiar o governo com caminhos a serem consolidados e melhor explorados.

Palavras-chave: gestão pública; gestão do conhecimento; inteligência; análise comparativa qualitativa; conjuntos fuzzy.

\begin{tabular}{|c|c|c|c|c|c|c|c|c|c|}
\hline & 1 & 2 & 3 & 4 & 5 & 6 & 7 & 8 & 9 \\
\hline $1^{\text {st }}$ round & $\stackrel{\infty}{2}$ & 2 & & & & & & & \\
\hline $2^{\text {nd }}$ round & $\stackrel{0}{2}$ & & & & & & & & \\
\hline $3^{\text {rd }}$ round & $\frac{8}{2}$ & & & & & & & & \\
\hline $4^{\text {th }}$ round & $\stackrel{\infty}{2}$ & & & & & & & & \\
\hline $5^{\text {th }}$ round & 2 & & & & & & & & \\
\hline
\end{tabular}




\section{INTRODUCTION}

The intensive use of information and communication technology (ITC) in public management led to a considerable increase in the flow of data and information both from society to governmental organizations and vice-versa. This context demanded greater attention from public management regarding the administration of information and knowledge produced and used. According to the Forrester Research, published in the journal Information Week Government (Welsh, 2014), government agencies must seek effective ways to use data to meet citizens' expectations. In addition, service delivery must be based on the unprecedented exponential volume of data and consider the widespread mobile connectivity (Scholl \& Scholl, 2014; Gil-Garcia, Zhang, \& PuronCid, 2016).

Research shows that governments at different levels are adopting tools and applications to improve service delivery, increasing coordination, and quickly responding to the rapid changes in the environment (Gil-Garcia, Helbig, \& Ojo, 2014; Paula \& Rover, 2012; Ribeiro, Pereira, \& Benedicto, 2013). One of these management tools is the government's intelligence activity, which despite being in the early stages of development, contributes to a new model of public service delivery (Schedler, Guenduez, \& Frischknecht, 2019).

The structure of the government's intelligence activity based on the use of data and information lead to quality decision-making of public managers and the development of new public policies. Cavalcante (2018) suggests that the last decades' economic, social, and political-administrative transformations have effectively enhanced a variety of restructuring processes, improving service delivery and the functioning of the Brazilian public sector.

A new form of thinking public management entails goals such as the development of an agile public administration regarding effectiveness in service delivery and resolution of issues of government and society, interdepartmental collaboration, and the implementation of a creative mix of emerging technologies for innovation in the public sector (Eom, Choi, \& Sung, 2016; Liu \& Zheng, 2015). New management processes, such as knowledge and intelligence management, prove to be effective in transforming data and information from the external environment in relevant knowledge to quality decisionmaking of public managers (Gil-Garcia et al., 2016;
Johnston \& Hansen, 2011; Monavvarian \& Kasaei, 2007; Shinoda, Maximiano, \& Sbragia, 2015).

When adopting intelligence processes involving activities of monitoring, observation, collection, interpretation, creation of meaning, and dissemination of data, organizations can select sensitive, useful, and evidence-based information that contributes to assertive decision-making (Gil-Garcia et al., 2016; JanissekMuniz \& Blanck, 2014; Scholl \& Scholl, 2014). In turn, knowledge management (KM) refers to a series of practices and techniques that organizations adopt to create, share, and explore knowledge to achieve organizational goals (Davenport, 1997; Nonaka \& Takeuchi, 2008; Arora, 2011; Jain \& Jeppesen, 2013).

KM improves the capacity to carry out public activities, with practices that increase the effectiveness of public services, and enhance the communication among the management levels (Wiig, 2002; Monavvarian \& Kasaei, 2007). These studies demonstrate the importance of processes of knowledge and intelligence management for quality decision-making (Alavi \& Leidner, 2001; Desouza, 2005; Hazlett, McAdam, \& Beggs, 2008; Johnston \& Hansen, 2011; Linders, Liao, \& Wang, 2015; Shinoda et al., 2015). While strategic intelligence activities prioritize looking at the external environment and its relationship with the organization, $\mathrm{KM}$ has an internal perspective, focusing on the knowledge already existing in the organization (Benedetti \& Janissek-Muniz, 2009).

Although there are studies on both intelligence and knowledge management in public management, there is a gap in the literature regarding the association between them. The Public Management Excellence Model (or MEGP) (Ministério do Planejamento, 2016) reinforces the importance of analyzing intelligence and KM together. In the MEGP, the pillar 'information and knowledge' supports the evaluation and processing of data and facts of both the organization (internal) and the environment (external), recognizing that the data and facts of the environment are not under the organization's direct control, but may influence its performance. In addition, Terra and Almeida (2008) argue that the study of the concepts of $\mathrm{KM}$ and intelligence, as well as the development of activities related to processes, should be treated together. For the authors, these elements should be aligned with the organizational strategy, seeking synergies and optimal allocation of resources and time.

Additionally, there are few reported efforts in the literature (1) to leverage the use of social data to build smart governments; (2) seeking the effective use of data and information from citizens; (3) to analyze 
the dynamic interactions among stakeholders; and (4) to influence and develop public policies (Bernardes, Andrade, Novais, \& Lopes, 2017; McBride, Aavik, Lalvet, \& Krimmer, 2018; Przeybilovicz, Cunha, Macaya, \& Alburquerque, 2018). In this sense, the research question guiding this study is: Based on the processes of intelligence and KM, what are the effective paths to achieving quality decision-making of public managers?

Thus, the objective of this study is to analyze how public managers apply the processes of intelligence and $\mathrm{KM}$ for quality decision-making. The study first analyzes the issues related to intelligence and $\mathrm{KM}$ in public management and then interviews seventeen public managers. The data collected through the interviews were analyzed using content analysis, and later, to define paths, a qualitative comparative analysis was applied.

This research contributes to expanding the understanding of intelligence and $\mathrm{KM}$ in public management, recognizing the utility of this combination in a context of an unprecedented amount of data and information, which need to be monitored, explored, understood, transformed into knowledge, and converted into actions to qualify the public managers' decisionmaking. As for its applicability, the study presents paths for governments to explore and consolidate, leading to better use of data and information from the context to improve decision-making.

The structure of the article includes this introduction to the theme, followed by a section presenting the concepts of intelligence and $\mathrm{KM}$ and their combination in the context of public management. The next section discusses the methodology and the techniques adopted, particularly the qualitative comparative analysis, followed by the study's results. Finally, the article presents discussions, conclusions, and directions for future research.

\section{KNOWLEDGE MANAGEMENT AND INTELLIGENCE IN THE PUBLIC CONTEXT}

In the 1990s, the Brazilian government began a process of modernizing public administration, focusing on efficiency through reducing costs and applying a result-oriented public activity, adopting managerial and less bureaucratic assumptions (Abrucio, 1997; Batista, 2012; Klering, Porsse, \& Ghadagnin, 2010; Paula, 2005; Pereira, 1996). According to Ribeiro, Pereira and Benedicto (2013), public administration reforms have contributed to improving political decision-making capacity and to the decentralization of the state, with the implementation of horizontal coordination and modernization of human management potential. This trend is based on building a more participatory, efficient, and integrated public administration (Capobiango, Nascimento, Silva, \& Faroni, 2013; Paula, 2005; Secchi, 2009), providing better public management in service delivery.

Rezende and Frey (2005), recognize the potential of expanding the number and types of actors involved in public management. For the authors, these new directions of public administration and public policy management require the mobilization of all knowledge available in society to improve the administrative performance and democratization of decision-making processes. Studies also point out the importance of acquiring data to be transformed into information and knowledge to improve decision-making in the public sector (Gil-Garcia, Pardo, \& Aldama-Nalda, 2013; Scholl \& Scholl, 2014), since smart governments can potentially feel and react to the environment based on data relevant to decision-making (Gil-Garcia et al., 2016).

Along the same vein, the Brazilian National Program for Public Management and Bureaucratization (known as Gespública) has sought, since the 2000s, to support the development and implementation of solutions that allow a continuous improvement in the management of public organizations and their impacts on citizens. Information and knowledge are presented as a fundamental pillar to achieving one of the main objectives of the program, which is the mobilization of the Brazilian public administration toward result-driven management (Ministério do Planejamento, 2016).

The process of intelligence in public management is aligned with the objectives of administrative modernization. It involves particular issues when compared to the private sector. Several authors emphasize the importance of continuous processes for monitoring the environment and analyzing data and information in government (Cepik, 1997, 2005; Desouza, 2005; Johnston \& Hansen, 2011; Linders et al., 2015). Issues related to the effectiveness of public activity and the delivery of quality public services, based on the use of information from the environment, are characteristics indicating the use of intelligence processes in public management (Gil-Garcia et al., 2014; Scholl \& Scholl, 2014).

According to Rezende (2012), intelligence in public administration refers to the use of systematic, personalized, and timely information and knowledge for decision-making. It aims to help public managers 
deal with complexity and uncertainties through coordination, continued involvement, access to open data and shared information (Gil-Garcia et al., 2014; Scholl \& Scholl, 2014), in order to take advantage of the population's potentially latent skills and knowledge (Johnston \& Hansen, 2011).

The literature shows important dimensions of the intelligence process in public management. First, the support of top management by encouraging the monitoring of the environment to capture relevant data and information for the construction of more efficient public administration (Gil-Garcia et al., 2016). Second, the collaboration and participation of people as recipients of data and information relevant to the organization and obtained through monitoring the environment (Gil-Garcia et al., 2016; Johnston \& Hansen, 2011; Paula \& Rover, 2012). Finally, the use of information and communication technology to collect data from the external environment, as well as assisting in data and information sharing among interested parties (Paula \& Rover, 2012; Scholl \& Scholl, 2014).

However, it is not enough to obtain information from the environment through intelligence processes. All knowledge generated from the data and information collected externally and that produced in the organization must be subject to management (Tzortaki \& Mihiotis, 2014). Therefore, the knowledge management (KM) process is established based on the organization's capacity to gather, store, and transfer knowledge, providing access to knowledge sources through mechanisms of identification and information retrieval, in order to apply such knowledge to the organization's specific needs (Alavi \& Leidner, 2001).

According to Riege and Lindsay (2006), building an effective government and developing knowledge-based public policies require the adoption of management that systematically and effectively captures, disseminates, discloses, and applies organizational knowledge. The public management must use practices and techniques to create, share, and explore knowledge that can assist in achieving organizational goals (Jain \& Jeppesen, 2013). In this sense, there is an effort by government agencies to adopt KM practices to create innovative and complex systems that connect people with relevant information and knowledge to develop their activities (Riege \& Lindsay, 2006), considering that people's knowledge is a central value to an organization (Voronchuk \& Starineca, 2014).

The analysis of $\mathrm{KM}$ in the field of public management suggests important dimensions to be considered. Three of them stand out. First, the support of top management for the creation, dissemination, and storage of organizational knowledge, to develop organizational policies oriented to learning and KM (Hazlett et al., 2008; Lindner \& Wald, 2011; Shinoda et al., 2015).Second, the use of ICT as a facilitator in the development of the KM process, since ICT allows to quickly obtain, share, and store knowledge (Arora, 2011; Dawes, Cresswell, \& Pardo, 2009; Mao, Liu, Zhang, \& Deng, 2016; Schutte \& Barkhuizen, 2015). Finally, the dimension of human capital stands out as the leading role of the KM process. Knowledge is created, obtained, disseminated, and stored in the organization and subsidizes decision-making, but the decisions are made by people (Arora, 2011; Davenport, 1998; Monavvarian \& Kasaei, 2007; Voronchuk \& Starineca, 2014; Wiig, 2002).

The analysis of the concepts of intelligence and $\mathrm{KM}$ in government helps to establish some fundamental factors that permeate both processes. For example, the use of ICT and the role of people as primary agents of such processes. In addition, the support of top management and issues of culture and organizational incentives appear as important factors in building an organization that efficiently captures, transforms, and manage information and knowledge.

The combination of the concepts of intelligence and $\mathrm{KM}$, considering the context of the public sector, reveals that ICT, human capital (people), and the support of top management are crucial factors in the operationalization of the processes. In addition, the government's efficiency and effectiveness, and quality decision-making of public managers, appear as consequences of the effective use of intelligence and KM mechanisms in the development of public activity. Thus, intelligence processes are established from the monitoring of the external environment for capturing data and information relevant to the organization (Janissek-Muniz, Lesca, \& Freitas, 2006). KM seeks to transform data and information from the environment into knowledge to be shared, explored, and used in decision-making (Gil-Garcia et al., 2013; Johnston \& Hansen, 2011; Wiig, 2002).

To resume the main points listed in the theoretical analysis, Table 1 presents perspectives, authors, and basic assumptions related to the processes of intelligence and $\mathrm{KM}$, focusing on the context of public management.

The studies presented in this literature review allow inferring the relevance of intelligence and KM processes for public management and the need for continued research in this area. The intention is to consolidate them as crucial processes for quality decision-making of public managers. 
Table 1. Theoretical perspectives.

\begin{tabular}{|c|c|c|}
\hline Category & Theoretical assumptions & Authors \\
\hline Knowledge management & $\begin{array}{l}\text { Knowledge management involves creating, storing, disseminating, } \\
\text { protecting, sharing, and using knowledge to maximize the efficiency } \\
\text { of the organization. Knowledge is an asset that must undergo } \\
\text { efficient management and be constantly renewed to generate a } \\
\text { return and competitive advantage. }\end{array}$ & $\begin{array}{l}\text { Alavi and Leidner (2001); Davenport (1997); Gaspar, } \\
\text { Santos, Donaire, Kuniyoshi and Prearo (2016); Gold, } \\
\text { Malhotra and Segars (2001); Nonaka (1994); Nonaka } \\
\text { and Konno (1998); Nonaka and Takeuchi (2008); Wiig } \\
(1997,2002) \text {. }\end{array}$ \\
\hline Intelligence & $\begin{array}{l}\text { The ability of organizations to collect, analyze, and disseminate data } \\
\text { and information (relevant to the development of their activities) } \\
\text { from the external environment, in advantage to their objectives and } \\
\text { strategies and reducing uncertainties in decision-making. }\end{array}$ & $\begin{array}{l}\text { Andriotti, Freitas and Janissek-Muniz (2008); } \\
\text { Davenport (1998); Fachinelli, Glacomello, Rech and } \\
\text { Bertolini (2013); Janissek-Muniz et al. (2006); Janissek- } \\
\text { Muniz and Blanck (2014); Rios, Strauss, Janissek-Muniz } \\
\text { and Brodbeck (2011). }\end{array}$ \\
\hline $\begin{array}{l}\text { Convergence between } \\
\text { intelligence and } \mathrm{KM} \text { in } \\
\text { public manage-ment }\end{array}$ & $\begin{array}{l}\text { Support of top management as an organizational incentive for } \\
\text { the creation, sharing, and storage of organizational knowledge. } \\
\text { Creation of an organizational culture aimed at monitoring the } \\
\text { environment with the objective of capturing data and information. } \\
\text { The use of ICT favors the sharing of information and knowledge } \\
\text { among stakeholders, i.e., technology is a facilitator in capturing } \\
\text { data and information from the environment. Human capital has } \\
\text { a leading role in KM since people are the decision-makers who } \\
\text { use the knowledge created, obtained, disseminated, and stored } \\
\text { in the organization. It is crucial to take advantage of skills and } \\
\text { knowledge often latent in the crowd and seek people's collaboration } \\
\text { and participation to increase efficiency and effectiveness of public } \\
\text { activity. People are recipients of data and information from the } \\
\text { environment. }\end{array}$ & $\begin{array}{l}\text { Dawes, Cresswell and Pardo (2009); Gil-Garcia et al. } \\
\text { (2013); Gil-Garcia et al. (2016); Hazlett, Mcadam and } \\
\text { Beggs (2008); Johnston and Hansen (2011); Lindner } \\
\text { and Wald (2011); Mao, Liu, Zhang and Deng (2016); } \\
\text { Shinoda, Maximiano and Sbragia (2015); Monavvarian } \\
\text { and Kasaei (2007); Paula and Rover (2012); Riege and } \\
\text { Lindsay (2006); Scholl and Scholl (2014); Voronchuk } \\
\text { and Starineca (2014); Wiig (1997, 2002). }\end{array}$ \\
\hline $\begin{array}{l}\text { Quality decision-making } \\
\text { of public managers }\end{array}$ & $\begin{array}{l}\text { Contribution to the participation of citizens and organizations } \\
\text { in public management. Improving the quality of life through the } \\
\text { development of intellectual capital and increasing the number } \\
\text { of knowledge workers in society. Public managers decision- } \\
\text { making based on relevant data and information, improving public } \\
\text { administration: better service delivery, overcoming complex } \\
\text { challenges, agile public management, effective public policies, and } \\
\text { programs. }\end{array}$ & $\begin{array}{l}\text { Gil-Garcia et al. (2013); Gil-Garcia et al. (2016); } \\
\text { Johnston and Hansen (2011); Monavvarian and Kasaei } \\
\text { (2007); Scholl and Scholl (2014); Wiig (2002). }\end{array}$ \\
\hline
\end{tabular}

\section{METHODOLOGY}

The methodology adopted to pursue the objective of analyzing how public managers apply the processes of intelligence and KM for quality decision-making consisted of, first, a literature review on intelligence and knowledge management $(\mathrm{KM})$ in the context of public management. The review allowed identifying elements of both intelligence and $\mathrm{KM}$, establishing a research protocol. As for KM, the elements observed were creating, transforming, structuring, and sharing organizational knowledge. In the case of intelligence, monitoring the environment and identifying, organizing, and using data and information about the environment stood out. The next step consisted of empirical research, adopting a qualitative and exploratory approach. The data collection method was semi-structured interviews, and the analysis was carried out using content analysis and qualitative comparative analysis (QCA).

\section{Data collection}

According to Myers (2013), qualitative researchers claim that it is practically impossible to understand why someone did something or why something happened in an organization without talking to people about it. To understand how public managers apply the processes of intelligence and $\mathrm{KM}$ in the development of public activity, the study chose to talk to people involved in this task, using semi-structured interviews.

The study's target audience was government employees working as public managers, i.e., exercising managerial activities in state secretaries linked to the executive branch of one of the states in southern Brazil. The interviewees were chosen for convenience, proximity, and accessibility. During the interviews, the participants were asked to recommend others who could 
contribute to this research. The final number of semistructured interviews was defined by saturation.

The interviews were conducted between April and May 2017, with seventeen participants. Fifteen (88\%) of them were male, eleven (65\%) have been in the public service for more than ten years, and twelve (71\%) received financial incentives (bonus for productivity) at the agency where they work. Eleven (65\%) had postdegrees and worked in different relevant areas such as inspection and collection, quality of public spending, projects and system, public procurement. (Table 2).

Table 2. Interviewees' profile.

\begin{tabular}{|c|c|c|c|c|c|}
\hline Interviewee & $\begin{array}{c}\text { Length of service } \\
\text { (years) }\end{array}$ & Gender & $\begin{array}{l}\text { Function in the } \\
\text { public agency }\end{array}$ & Area of work & Education \\
\hline E1 & 10 & M & Manager & Inspection and collection & Post-degree \\
\hline E2 & 25 & M & Manager & Projects and systems & Post-degree \\
\hline E3 & 7 & M & Manager & Quality of public spending & Degree \\
\hline E4 & 10 & M & Manager & Budget planning & Post-degree \\
\hline E5 & 25 & M & Director & Administrative management & Master \\
\hline E6 & 7 & M & Manager & Financial planning and cash flow & Post-degree \\
\hline E7 & 23 & M & Manager & Control of public debt & Degree \\
\hline E8 & 21 & M & Director & Projects and systems & Post-degree \\
\hline E9 & 18 & M & Manager & Personnel development & Degree \\
\hline E10 & 7 & M & Manager & Financial planning & Master \\
\hline E11 & 25 & M & Director & Quality and organizational development & Master \\
\hline E12 & 39 & M & Manager & Institutional relations & Degree \\
\hline E13 & 38 & M & Director & Public procurement & Master \\
\hline E14 & 6 & M & Manager & Projects and systems & Post-degree \\
\hline E15 & 8 & $\mathrm{~F}$ & Coordinator & Legal advice & Post-degree \\
\hline E16 & 2 & $\mathrm{~F}$ & Manager & Personnel development & Degree \\
\hline E17 & 36 & M & Manager & Planning and modernization & Degree \\
\hline
\end{tabular}

Note. Source: elaborated by the authors. 
After data collection, the interviews were transcribed, resulting in 92 pages of raw data. The content was organized and structured, systematizing the ideas and analyzing how public managers understand and apply the processes of intelligence and KM for the development of public activity, and for quality decisionmaking. Afterwards, the referred data and information were analyzed through the association of two techniques: content analysis and qualitative comparative analysis (QCA).

\section{Data analysis}

The techniques applied were content analysis and fuzzy-set qualitative comparative analysis (QCA). After the content analysis that identified and organized the main elements portrayed in the interviews, some conditions were established. The conditions were calibrated to carry out the qualitative comparative analysis. The procedures and analyzes are described in this subsection.

\section{Content analysis}

The data analysis followed the steps described in work by Bardin (2011). The content transcribed was analyzed to identify categories. Table 3 presents the categorization of data for content analysis, which was based on the theoretical framework and the understanding of public managers regarding intelligence and knowledge management (KM), considering the importance of these processes for the development of public activity. In addition, it was possible to verify convergent points of approximation of the concepts in the public sectors and the perceived evolution in the structuring of processes in the public sector according to the view of the public managers interviewed.

Table 3. Categorization of information.

\begin{tabular}{|c|c|c|c|}
\hline Raw data & Category & Sub-category & Theoretical framework \\
\hline \multirow{11}{*}{$\begin{array}{l}\text { Transcription } \\
\text { of interviews }\end{array}$} & \multirow{3}{*}{$\begin{array}{l}\text { Knowledge } \\
\text { management }\end{array}$} & Knowledge management process & \multirow{3}{*}{$\begin{array}{c}\text { Alavi and Leidner (2001); Davenport (1997); Gaspar et al. (2016); Gold } \\
\text { et al. (2001); Nonaka (1994); Nonaka and Konno (1998); Nonaka and } \\
\text { Takeuchi (2008); Wiig (1997, 2002). }\end{array}$} \\
\hline & & Knowledge creation & \\
\hline & & $\begin{array}{l}\text { Knowledge use, storing, and } \\
\text { dissemination }\end{array}$ & \\
\hline & \multirow{4}{*}{ Intelligence } & Intelligence activities and teams & \multirow{4}{*}{$\begin{array}{l}\text { Andriotti et al. (2008); Davenport (1998); Fachinelli et al. (2013); Janissek- } \\
\text { Muniz et al. (2006); Janissek-Muniz e Blanck (2014); Rios et al. (2011). }\end{array}$} \\
\hline & & $\begin{array}{l}\text { Collection of data and } \\
\text { information }\end{array}$ & \\
\hline & & $\begin{array}{l}\text { Analysis and use of data and } \\
\text { information }\end{array}$ & \\
\hline & & $\begin{array}{l}\text { Dissemination of data and } \\
\text { information in the organization }\end{array}$ & \\
\hline & \multirow{3}{*}{$\begin{array}{l}\text { Convergence } \\
\text { between intelligence } \\
\text { and } \mathrm{KM} \text { in public } \\
\text { management }\end{array}$} & Support of top management & $\begin{array}{l}\text { Gil-Garcia et al. (2013); Gil-Garcia et al. (2016); Hazlett et al. (2008); } \\
\text { Johnston and Hansen (2011); Lindner and Wald (2011); Monavvarian } \\
\text { and Kasaei (2007); Riege and Lindsay (2006); Scholl and Scholl (2014); } \\
\text { Shinoda et al. (2015); Wiig (2002). }\end{array}$ \\
\hline & & Use of ICT & $\begin{array}{l}\text { Alhamoudi (2015); Arora (2011); Dawes et al. (2009); Davenport (1998); } \\
\text { Gaspar et al. (2016); Gil-Garcia et al. (2013); Gil-Garcia et al. (2016); Gold } \\
\text { et al. (2001); Jain and Jeppesen (2013); Johnston and Hansen (2011); Mao } \\
\text { et al. (2016); Paula and Rover (2012); Pee and Kankanhalli (2016); Scholl } \\
\quad \text { \& Scholl, 2014; Schutte and Barkhuizen (2015); Wiig (2002). }\end{array}$ \\
\hline & & Human capital & $\begin{array}{l}\text { Arora (2011); Davenport (1998); Dawes et al. (2009); Gil-Garcia et al. } \\
\text { (2013); Gil-Garcia et al. (2016); Johnston and Hansen (2011); Mao et al. } \\
\text { (2016); Monavvarian and Kasaei (2007); Paula and Rover (2012); Scholl \& } \\
\text { Scholl, 2014; Voronchuk e Starineca (2014); Wiig (1997, 2002). }\end{array}$ \\
\hline & $\begin{array}{l}\text { Quality decision- } \\
\text { making of public } \\
\text { managers }\end{array}$ & - & $\begin{array}{l}\text { Gil-Garcia et al. (2013); Gil-Garcia et al. (2016); Johnston and Hansen } \\
\text { (2011) Monavvarian and Kasaei (2007); Scholl and Scholl (2014); Wiig } \\
\text { (2002). }\end{array}$ \\
\hline
\end{tabular}

Note. Source: elaborated by the authors. 
Regarding the influence of the processes of intelligence and KM in quality decision-making of public managers, all seventeen interviewees listed the elements 'data from the external environment' and 'information and knowledge produced internally by the organization' as of paramount importance and definitive for quality decision-making, even if there were no intelligence or KM processes structured in the organization. The interviewees' response corroborates the theory, both regarding the knowledge sharing between the lower and upper management and the search for relevant data and information to qualify decision-making to overcome complex public administration challenges (Wiig, 2002; Johnston \& Hansen, 2011; Gil-Garcia et al., 2013).

One of the interviewees mentioned the need for faster, more consistent, and transparent decisions (Riege \& Lindsay, 2006), emphasizing that "if data and information from the environment were not used, decision-making processes would be dependent, perhaps subjective, influenced by the capacity of a manager to pressurize. Other [decisions] could not be as clear [if not made based on data and information from the environment]." Another issue that deserves attention concerns the development of analytical capabilities so that employees can process data and information and move forward in evidence-based decision-making (Malomo \& Sena, 2017; Valle-Cruz \& SandovalAlmazan, 2018). One interviewee considers there is much to be improved regarding the concern over the use of data and information for quality decision-making about the development of public policies. According to the interviewee, "a more structured process of knowledge management is lacking, sometimes I need information about something, and I need to call someone, so it is restricted to interpersonal relationships." Based on the issues that emerged in the content analysis, when the information was categorized, and in order to map the causal configurations related to the processes of intelligence and $\mathrm{KM}$ that could potentially lead to quality decision-making of public managers, the study adopted the fuzzy-set qualitative comparative analysis technique, presented below.

\section{Qualitative comparative analysis}

The application of the fuzzy-set qualitative comparative analysis ( $\mathrm{f}$ Q $\mathrm{QCA}$ ) was considered adequate in this case because it allows identifying causal configurations that lead to the presence or absence (represented by the symbol $\sim$ ) of a given result, with more than one solution for each given objective (Rihoux \& Ragin, 2009). The fsQCA offers, by inserting values between 0 and 1 , a closer perception of the situations studied (Ragin, 2000).

The analysis identified which configurations of causal conditions led to quality decision-making of public managers, as well as the configurations that led to the absence of the respective result. Each configuration of the causal conditions and the associated result are designated as a case (Fiss, 2007). The causal conditions in the fsQCA are related to the dimensions considered as relevant to the use of intelligence and KM processes in the context of public management, based on the theoretical framework and previous content analysis.

The conditions related to quality decisionmaking of public managers are the use of knowledge management processes $(K M)$, intelligence (intel), and the support of top management (topman), as well as the influence of the length of service (length) and gender of the respondent (gen). The dimensions related to the use of ICT and the participation of people were not analyzed because they showed, based on the theoretical framework and content analysis, to be necessary in both cases, with no need for incorporation in the study as a way to bring a differential for research.

\section{Calibration of conditions}

QCA was developed to analyze configurations of conventional Boolean sets. The approach analyzes whether a given variable is part of a given set, through the definition of crisp sets (sets of conditions that only assume values 0 and 1). Crisp set qualitative comparative analysis (csQCA) offers sets with simple data composed of binary variables, coded as 1 for 'present,' and 0 for 'absent' (Rihoux \& Ragin, 2009). The binary variable in this study is the condition 'gender.'

In addition to working with existing binary variables in the conventional set approach, the fuzzy set qualitative comparative analysis ( $\mathrm{fs}_{\mathrm{Q}} \mathrm{QCA}$ ) considers values between 0 and 1 , not just ' 0 ' or ' 1 .' The fsQCA approach accepts alternative configurations of conditions, equifinality, and asymmetry (Fiss, 2007), Fuzzy sets offer a detailed and closer perception of the situations studied (Ragin, 2000). According to the author, the connection between theory and data analysis is essential in social sciences, and fuzzy sets improve such connection since they can be designed to fit and 'fill in' theoretical concepts.

Calibration is the process of classifying conditions in each case, from 'fully in' (1.00) to 'fully out' (0.00), and implies theoretical and empirical knowledge about the variables (Ragin, 2005; 2008). In this study, binary and calibrated categorical variables were adopted to allow 
the use of fsQCA. Each category was associated with a significant set (full membership, point of maximum ambiguity, and full non-membership). To calibrate the fuzzy set data, a mechanical procedure (based on theory) or a manual procedure (based on evidence) is used. This study adopted a manual procedure to calibrate causal conditions and results, based on the analysis of the interviews conducted with public managers.

The process of intelligence and KM were analyzed based on their various processes. Therefore, the variable 'intelligence' (intel) was considered as presenting 'full membership' when at least one of its processes (monitoring of the environment, use of information, or internal dissemination of data and information) resulted in a given set. The same procedure was adopted for the variable 'knowledge management' $(K M)$, regarding the type of membership to a given set observed in the analysis of its processes (knowledge creation, knowledge storage, knowledge use, or knowledge dissemination).

For the variables $K M$, intel, and support of top management (topman), the calibration process was established based on the definition of 'levels of importance' of the respective processes and support: nonimportant process/support (0.00); minimally important process/support (0.25); moderately important process/ support (0.50); significantly important process/support (0.75); totally important process/support (1.00). The use of abbreviations for the variables helps to understand and describe the causal configurations.

The variable 'length of service' (length) presents several values and makes up a fuzzy set. Variables with fuzzy values show the degree to which different cases belong to a given set, evaluating different degrees of association between being 'fully in' and 'fully out.' Such calibration is only possible with theoretical and substantive knowledge, which is essential for the specification of the three qualitative breakpoints: full non-membership, point of maximum ambiguity, and full membership (Ragin, 2005). Therefore full membership adherence (0.90) was attributed for 39 years of public service, full non-membership (0.10) was attributed for two years of public service, and the point of maximum ambiguity $(0.50)$ for fourteen years of public service.

Gender (gen) is a binary variable. Regarding the result 'quality in decision-making of public managers,' the calibration process was established by defining the levels of importance: 0.00 (no quality); 0.25 (poor quality); 0.50 (average quality); 0.75 (a lot of quality); 1.00 (total quality). Table 4 shows the cuts used in the calibration for the causal conditions; the calibration used in this study is presented for each condition.

Table 4. Calibration of conditions (variables).

\begin{tabular}{cc}
\hline Conditions and objective & Calibration \\
\hline Knowledge management $(K M)$ & $(0.00 ; 0.25 ; 0.50 ; 0.75 ; 1.00)$ \\
Intelligence (intel) & $(0.00 ; 0.25 ; 0.50 ; 0.75 ; 1.00)$ \\
Support of top management (topman) & $(0.00 ; 0.25 ; 0.50 ; 0.75 ; 1.00)$ \\
Length of service (length) & $(39 ; 14 ; 2)$ \\
Gender $($ gen $)$ & Binary variable, $0=$ Male; $1=$ Female \\
Quality decision-making of public managers (quali) & $(0.00 ; 0.25 ; 0.50 ; 0.75 ; 1.00)$ \\
\hline Note. Source elate
\end{tabular}

Note. Source: elaborated by the authors. Calibration is the process of classifying the conditions in each case, from 'full in' (1.00) to 'full out' (0.00). The process implies a theoretical and empirical knowledge about the variables (Ragin, 2005; 2008).

\section{Analysis of the necessary conditions}

Causal conditions are assessed on their need and sufficiency. The degree of need for the causal condition indicates its relevance in the process of achieving a particular result. The degree of sufficiency demonstrates the extent to which the condition explains the result obtained (Fiss, Sharapov, \& Conqvist, 2013).
For Ragin (2000), needed conditions must present a consistency value superior to 0.80 . When addressing the needed conditions for the result 'quality decisionmaking of public managers,' the study found consistency values superior to 0.90 for men $(\sim$ gen $)$, support from top management (topman), knowledge management $(K M)$, and intelligence (intel), demonstrating the relevance of these elements. As for the needed condition for the 
absence of the result 'quality decision-making of public managers,' the findings that point to the absence of support of management ( topman) and to the absence of knowledge management $(\sim K M)$ are representative, presenting a consistency greater than 0.90 .

\section{Analysis of causal configurations}

Following the best practices in the literature, the intermediate solutions for the results of the sufficiency analysis are reported. These solutions are not the most (parsimonious) nor the least (complex) rigorous (Fiss, 2011; Ragin, 2008). The solutions are sets of causal configurations of conditions that indicate the alternative paths that lead to the analyzed result. Conditions may be 'core' and 'peripheral.' The first are those conditions present in both parsimonious and intermediate solutions. Peripheral conditions are present only in intermediate solutions (Ragin, 2000, 2008; Fiss, 2011; Fiss et al., 2013). It is worth stressing that parsimonious solutions have only the core conditions that are highly linked to the result, while the intermediate ones are more conservative and assume the more plausible simplified hypotheses (Ragin, 2008).
Regarding quality decision-making of public managers, the results of the sufficiency analysis show an intermediate solution with a single configuration with consistency superior to 0.80 , complying with the threshold suggested by Ragin (2008). Regarding the absence of quality decision-making of public managers, the intermediate solution shows three causal configurations with consistency superior to 0.89 , also complying with the threshold established by Ragin (2008) or Fiss (2011). Such a difference in the quantity of causal configurations for quality decision-making of public managers (and its absence) are important results of the study.

The causal configurations presented in Table 5 show the core and peripheral conditions, both for the result 'quality decision-making of public managers' (quali) and for the absence of this result ( quali). Regarding quality decision-making of public managers, the intermediate solution offers a single configuration. As for its absence, the respective parsimonious solution shows three intermediate causal configurations. Table 5 considers intel for intelligence, $K M$ for knowledge management, topman for support of top management, gen for gender, and length for length of service.

Table 5. Causal configurations.

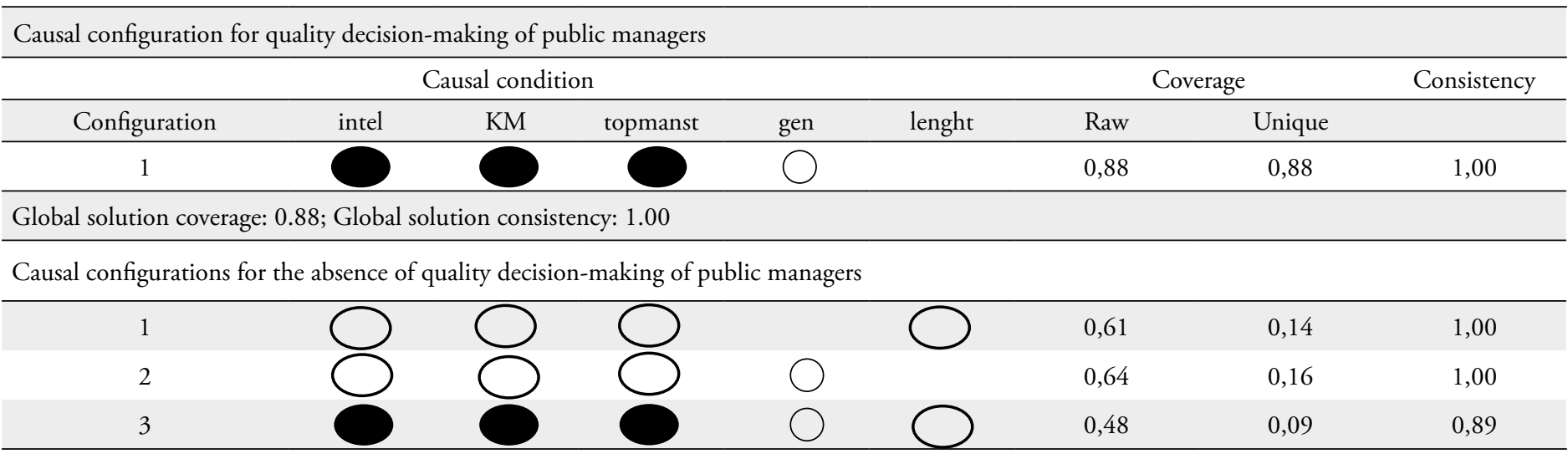

Global solution coverage: 0.86; Global solution consistency: 0.93

Note. Source: elaborated by the authors. Black circles $(\bullet)$ indicate the presence of the condition. Blank circles $(0)$ indicate the absence of the condition. Large circles indicate core conditions. Small circles describe peripheral conditions. Blank cells indicate that the condition does not contribute to the result (presence or absence).

From the analysis of the configurations, it is possible to infer that the fsQCA allows the variables to be causally related in one configuration without necessarily being related, or even inversely related, in other configurations. There may be alternative configurations of causal conditions for both the presence and the absence of the expected result, and such configurations reflect the three characteristics of fsQCA: (a) more than one configuration of causal conditions leads to the result and to its absence (alternative configurations of causal conditions); (b) alternative causal configurations can produce the same result (equifinality); (c) causal 
conditions of the result may differ from the causal conditions of its absence (asymmetry).

Table 5 allows deducing that the fsQCA produced only a causal configuration that leads to quality decisionmaking of public managers. Such a configuration, resulting from the intermediate solution, demonstrates that the combination of processes of intelligence, KM, support of top management, and the male manager lead to quality decision-making of public managers. The first two configurations regarding the absence of quality decision-making of public managers are symmetrical to the results obtained from the configuration for quality decision-making of public managers. These results are consistent with what was observed in the content analysis. The combined application of the two data analysis techniques - content analysis and QCA proved to be relevant for the development of the study, complementing and validating the research. The results obtained from the analysis of causal configurations are aligned with the findings of the content analysis and the inputs obtained from the literature, as discussed in the following subsection.

\section{Results validation}

The evaluation of a qualitative content analysis must consider its reliability and validity (Duriau, Reger, \& Pfarrer, 2007). Also, "the evaluation criteria for qualitative and quantitative research must be different" (Bryman \& Bell, 2003, p. 411). For Guba and Lincoln (2005), it is crucial to follow the principles of reliability and authenticity - grounded in the constructivism - in order to guarantee the validity of the analysis following the principles of reliability and authenticity borrowed from constructivism. Reliability encompasses four criteria equivalent to those of quantitative research: "credibility (which is parallel to internal validity), transferability (which is parallel to external validity), reliability (parallel to reliability), and confirmability (parallel to objectivity)" (Bryman \& Bell, 2003, p. 411).

For this study, the researchers digitally recorded in audio and then transcribed, in full, 17 interviews. The interviews allowed a full understanding of the phenomenon researched, validating the literature review. The initial analysis of the data collected with the interviews started by identifying relevant concepts and grouping them into categories (open coding). Open coding involves examining, comparing, conceptualizing, and categorizing data. The open coding process generates concepts that can later be grouped into categories (Bryman \& Bell, 2003, p. 586). The process was conducted by associating codes and creating categories and relationships among them. A unique classification was used for each code, which means that the categories were mutually exclusive, as recommended by Weber (1990), to restrict the categories to codes that unmistakably reflect them, which maximizes validity.

Authenticity was guaranteed (Guba \& Lincoln, 2005) based on the participation of several public managers with different lengths of service, different functions in the public agency, different areas of specialty, and different genres. Thus, ontological authenticity was provided, producing and offering public organizations a model that clarifies the rationale for quality decisionmaking of public managers. This contribution involves the causal configuration for quality decision-making of public managers and the causal configuration for the absence of quality decision-making of public managers.

The validity of the content analysis was assessed based on data saturation (Finfgeld-Connett, 2014). In qualitative studies, sampling must be intentional. The sampling method uses purposive sampling (or judgment, selective, or subjective sampling), which is a nonprobabilistic sampling, where researchers rely on their own judgment when choosing members of the population to participate in their study. The interviews take place until there is theoretical saturation, i.e., when there are trivial inputs, and the phenomenon becomes repetitive (Finfgeld-Connett, 2014). In this way, the sample size depends on sufficient participation to reach theoretical saturation. The theoretical saturation was reached after the 17th interview (Glaser \& Strauss, 1967).

The validity of the fsQCA was achieved by confirming the configurations based on the data. An example is a configuration for quality decision-making of public managers found in the speech of interviewee (I8): "The information and knowledge produced based on data from the environment qualify decision-making. These data influence because they bring additional, complementary elements so that you can make a better assessment of a particular scenario that involves decisionmaking." This result is in line with the literature, which points out the importance of knowledge management and the search for relevant data and information that qualify decision-making to overcome complex challenges in government (Gil-Garcia et al., 2013; Johnston \& Hansen, 2011; Wiig, 2002).

Likewise, it was possible to validate the causal configurations for the absence of quality decision-making of public managers. One example of these configurations was observed with the interviewee I10, who stressed that "many decisions end up having a political bias, and they are not based on data, information, and knowledge, which leads to the absence of quality decision-making." Interviewee I11 made comments in the same direction, 
saying that public managers sometimes acknowledge the information to qualify a decision-making process, but such information is not always used.

As for the third causal configuration, it is worth mentioning that, for a male manager with little time in public service, the processes of intelligence and KM are insufficient to produce the result of quality decisionmaking. This finding demonstrates a potential issue to be further explored in the future since neither the theoretical review nor the content analysis brought up issues related to gender and length of service. Therefore, the relationship between these characteristics and the analyzed result probably include conditions not evaluated in this study.

\section{DISCUSSION}

The literature review presented relevant aspects regarding the use of intelligence and knowledge management (KM) in the public sector. These aspects allowed identifying issues related to the support of top management, the use of ICT, and people's participation as elements that approximate the concepts of intelligence and $\mathrm{KM}$ and public management. It is observed that the association and application of the process of intelligence and $\mathrm{KM}$ in public management aim, among other aspects, to promote quality decision-making of public managers.

The analysis of the data collected from interviews with public managers shows that, in the public managers' point of view, there are complementary aspects between the concepts of intelligence and KM. The analysis also allowed verifying the perception of public managers regarding the importance of these processes (intelligence and $\mathrm{KM}$ ) in the public context, to examine the existence of these processes in a structured form when it comes to public management, and finally, identify paths that prove to be effective for quality decision-making of public managers. This objective is in line with the trend toward a more participatory, efficient, integrated public administration that provides better public management in delivering services (Capobiango et al., 2013; Paula, 2005; Secchi, 2009). The public managers interviewed recognize the importance of such processes for quality decision-making.

The interviewees recognize the importance of intelligence and $\mathrm{KM}$ processes for public management but point to a lack of structured KM processes within the public agencies where they work. The managers identified some isolated experiences of using such processes. However, knowledge, in general, is still rooted in people and knowledge-sharing is based on relationships among government employees, which must be a dynamic of concern for public management (Eom et al., 2016; Gil-Garcia et al., 2016; Johnston \& Hansen, 2011; Riege \& Lindsay, 2006; Scholl \& Scholl, 2014).

Public management receives a large amount of data and information from the environment, and, according to the interviewees, there are not enough staff to carry out the analysis of data and information about minor demands or irregularities with little social or financial impact on the state. This point demands more attention from the top public management since important insights may be withdrawn from these data to design public policies.

The qualitative comparative analysis (QCA) identified paths to quality decision-making of public managers by using processes of intelligence and knowledge management - or recognizing their absence. Such analysis proved to be in line with the literature and the content analysis, since the QCA indicated that processes of intelligence and KM, together with the other factors analyzed, lead to quality decision-making of public managers.

The three causal configurations found for the absence of quality decision-making of public managers represent an opportunity for future studies exploring the influence of gender and managers' length of service. The absence of length of service appears in two of the three configurations that lead to the absence of quality decision-making of public managers. However, the study was unable to identify a cause for this phenomenon, which may be related to either the lack of training or the lack of tacit knowledge of the organization and procedures, both acquired over time in the organization.

Additionally, future studies could examine the possibility of existing conditions that were not addressed in this study, and that may influence the quality decisionmaking of public managers. Conditions such as training and staff development can be an interesting path to study. Finally, it is emphasized that the use of two data analysis techniques, content analysis and QCA, proved to be interesting for the development of qualitative research. The techniques showed to complement and validate each other.

\section{FINAL CONSIDERATIONS}

This study provides an original contribution not addressed in the literature. It presents the causal configurations that lead to quality decision-making of public managers (as well as the causal configurations that lead to the absence of such result) using elements of 
intelligence and knowledge management $(\mathrm{KM})$ processes in the context of Brazilian public management. The findings suggest a path that leads to quality decisionmaking of public managers and three others leading to the absence of this result. These findings demonstrate the importance of intelligence and KM for quality decisionmaking in public administration, considering that data, information, and knowledge subsidize public managers' decision-making regarding service delivery and society's wellbeing.

The identification of paths leading to quality decision-making of public managers allows suggesting procedures to be adopted in governmental agencies to increase the effectiveness in public management. However, when identifying and following a path, it is crucial to maintain the conditions to keep going in the identified direction, at the same time as seeking new paths that may be even more effective to achieve the desired results. Knowing the paths that lead to the absence of quality decision-making of public managers represents an opportunity to avoid such configurations in public organizations and not to incur inappropriate decision-making.

\section{REFERENCES}

Abrucio, F. L. (1997). O impacto do modelo gerencial na administração pública: um breve estudo sobre a experiência internacional recente. Brasília, DF: ENAP. Retrieved from https://repositorio.enap.gov.br/bitstream/1/556/1/O\%20 impacto\%20do\%20modelo\%20gerencial\%20na\%20 Administra\%c3\%a7\%c3\%a3o\%20P\%c3\%bablica.pdf

Alavi, M., \& Leidner, D. E. (2001). Knowledge management and knowledge management systems: Conceptual foundations and research issues. MIS Quarterly, 25(1), 107-136. https://doi.org/10.2307/3250961

Alhamoudi, S. (2015). Knowledge Management Strategies in Public Sector-CaseStudy. China-USABusinessReview, 14(3), 159170. http://doi.org/10.17265/1537-1514/2015.03.004
This study brings a new way of analyzing conditions and proposing a sufficient path leading to quality decision-making of public managers. Future studies may focus on the issue of the influence of gender and length of service on quality decision-making of public managers, since the results suggest that there may be a relationship between gender and length of service with aspects of trust, regardless of the use of structured management processes.

Other directions for future research include a comparative analysis between public agencies with structured processes of intelligence and KM and those that do not present such processes. This comparison would possibly contribute to the analysis of determining factors of success in the implementation and development of processes of intelligence and KM to improve decisionmaking. This study can also be replicated in the private sector, examining large and small enterprises, family and multinational companies, as well as non-profit organizations.

Andriotti, F. K., Freitas, H., \& Janissek-Muniz, R. (2008). Informação informal e a monitoraçáo do ambiente organizacional: reflexóes e sugestóes para a área de TI. III Prêmio de INovação em Inteligência Competitiva. Congresso Ibero Americano de Gestão do Conhecimento e Inteligência Competitiva, Brasília, DF. Brazil. 2.

Arora, E. (2011). Knowledge management in public sector. Researchers World, 2(1), 165. Retrieved from $\quad \underline{\text { http://citeseerx.ist.psu.edu/viewdoc/ }}$ download?doi=10.1.1.474.3542\&rep=rep1 \&type $=$ pdf

Bardin, L. (2011). Análise de conteúdo. Lisboa: Ediçôes, 70. 
Batista, F. F. (2012). Modelo de gestáo do conhecimento para a administração pública brasileira: como implementar a gestão do conhecimento para produzir resultados em beneficio do cidadão. Brasília, DF: Ipea, 2012. Retrieved from https:// www.ipea.gov.br/portal/images/stories/PDFs/livros/ livros/livro modelodegestao vol01.pdf

Benedetti, F., \& Janissek-Muniz, R. (2009). Knowledge management: an important resource for the strategic intelligence. Anais do CONTECSI - International Conference on Information Systems and Technology Management, São Paulo, SP, Brazil, 6.

Bernardes, M. B., Andrade, F. P. de, Novais, P., \& Lopes, N. V. (2017). Reference model and method of evaluation for smart cities in government portals: a study of the Portuguese and Brazilian reality. Proceedings of the International Conference on Electronic Governance and Open Society: Challenges in Eurasia. ACM. https://doi.org/10.1145/3129757.3129781

Bryman, A., \& Bell, E. (2003). Business Research Methods. Hong Kong: Oxford University Press.

Capobiango, R. P., Nascimento, A. D. L. do, Silva, E. A., \& Faroni, W. (2013). Reformas administrativas no Brasil: Uma abordagem teórica e crítica. REGE Revista de Gestão, 20(1), 61-78. https://doi.org/10.5700/rege487

Cavalcante, P. (2018). Innovations in the Federal Government during the post-new public management era. Revista de Administração Contemporânea, 22(6), 885-902. https://doi.org/10.1590/1982-7849rac2018170391

Cepik, M. A. (1997). Inteligência, política e poder no Estado contemporâneo. Revista de Sociologia e Política, (9), 193196. Retrieved from http://professor.ufrgs.br/marcocepik/ publications/inteligencia-politica-e-poder-no-estadocontemporaneo-resenha

Cepik, M. (2005). Regime político e sistema de inteligência no Brasil: legitimidade e efetividade como desafios institucionais. Dados, 48(1), 67-113. https://doi.org/10.1590/S0011-52582005000100004

Davenport, T. H. (1997). Ten principles of knowledge management and four case studies. Knowledge and process Management, 4(3), 187-208. https://doi.org/10.1002/(SICI)10991441(199709)4:3<187::AID-KPM99>3.0.CO;2-A

Davenport, T. H. (1998). Ecologia da informação: Porque só a tecnologia não basta para o sucesso na era da informação. São Paulo: Futura.

Dawes, S. S., Cresswell, A. M., \& Pardo, T. A. (2009). From "need to know" to "need to share": Tangled problems, information boundaries, and the building of public sector knowledge networks. Public Administration Review, 69(3), 392-402. https://doi.org/10.1111/j.1540-6210.2009.01987 2.x
Desouza, K. C. (2005). Restructuring government intelligence programs: A few good suggestions. Government Information Quarterly, 22(3), 342-353. https://doi.org/10.1016/j.giq.2005.05.001

Duriau, V. J., Reger, R. K., \& Pfarrer, M. D. (2007). A content analysis of the content analysis literature in organization studies: research themes, data sources, and methodological refinements. Organizational Research Methods. 10(1), 5-34. https://doi.org/10.1177/1094428106289252

Eom, S. J., Choi, N., \& Sung, W. (2016). The use of smart work in government: Empirical analysis of Korean experiences. Government Information Quarterly, 33(3), 562-571. https://doi.org/10.1016/j.giq.2016.01.005

Fachinelli, A. C., Glacomello, C. P., Rech, J., \& Bertolini, A. L. (2013). Inteligência estratégica: desenvolvimento de uma escala para compreensão do construto. Revista Brasileira de Estratégia, 6(2), 179-191. https://doi.org/10.7213/rebrae.06.002.AO06

Finfgeld-Connett, D. (2014). Use of content analysis to conduct knowledge-building and theory-generating qualitative systematic reviews. Qualitative Research, 14(3), 341-352. https://doi.org/10.1177/1468794113481790

Fiss, P.C. (2007). A set-theoretic approach to organizational configurations. Academy of Management Review, 32(4), 1180-1198. Retrieved from https://pdfs.semanticscholar. org/901b/357c7d4ab59298bd0872554f3f34091c40ff. pdf

Fiss, P. C. (2011). Building better causal theories: A fuzzy set approach to typologies in organization research. Academy of Management Journal, 54(2), 393-420. https://doi.org/10.5465/amj.2011.60263120

Fiss, P. C., Sharapov, D., \& Cronqvist, L. (2013). Opposites attract? Opportunities and challenges for integrating large-N QCA and econometricanalysis. PoliticalResearch Quarterly, 66(1), 191-198. https://doi.org/10.1177/1065912912468269e

Gaspar, M. A., Santos, S. A. dos, Donaire, D., Kuniyoshi, M. S., \& Prearo, L. C. (2016). Gestão do conhecimento em empresas atuantes na indústria de software no Brasil: um estudo das práticas e ferramentas utilizadas. Informação \& Sociedade, 26(1), 151-166. Retrieved from http://hdl.handle.net/20.500.11959/brapci/91930

Gil-Garcia, J. R., Pardo, T. A., \& Aldama-Nalda, A. (2013). Smart cities and smart governments: Using information technologies to address urban challenges. Proceedings of the 14 th Annual International Conference on Digital Government Research. https://doi.org/10.1145/2479724.2479728

Gil-Garcia, J. R., Helbig, N., \& Ojo, A. (2014). Being smart: Emerging technologies and innovation in the public sector. Government Information Quarterly, 31, I1-I8. https://doi.org/10.1016/j.giq.2014.09.001

Gil-Garcia, J. R., Zhang, J., \& Puron-Cid, G. (2016). Conceptualizing smartness in government: An integrative and multi-dimensional view. Government Information Quarterly, 33(3), 524-534. https://doi.org/10.1016/j.giq.2016.03.002 
Glaser, B. G., \& Strauss, A. L. (1967). The discovery of grounded theory: Strategies for qualitative research. Chicago, IL: Aldine.

Gold, A. H., Malhotra, A., \& Segars, A. H. (2001). Knowledge management: An organizational capabilities perspective. Journal of management information systems, 18(1), 185-214. Retrieved from https://www. researchgate.net/publication/220591588 Knowledge Management An Organizational Capabilities Perspective/link/09e4150b6486954612000000/ download

Guba, E. \& Lincoln, Y. (2005). Paradigmatic controversies, contradictions and emerging confluences. In E. Guba, and Y. Lincoln. (Eds.). The Sage Handbook of Qualitative Research (pp. 191-215). Thousand Oaks, CA: Sage.

Hazlett, S., McAdam, R., \& Beggs, V. (2008). An exploratory study of knowledge flows: A case study of Public Sector Procurement. Total Quality Management, 19(1-2). https://doi.org/10.1080/14783360701602205

Jain, A. K., \& Jeppesen, H. J. (2013). Knowledge management practices in a public sector organization: The role of leaders' cognitive styles. Journal of Knowledge Management, 17(3), 347-362. https://doi.org/10.1108/JKM-11-2012-0358

Janissek-Muniz, R., \& Blanck, M. R. M. (2014). Weak signals management, entrepreneurship and uncertainty: A relational theoretical essay under the perspective of intelligence. Anais do CONTECSI - International Conference on Information Systems and Technology Management. São Paulo, SP, Brazil, 11. https://doi. org/10.5748/9788599693100-11CONTECSI/COMM$\underline{625}$

Janissek-Muniz, R., Lesca, H., \& Freitas, H. (2006). Inteligência estratégica antecipativa e coletiva para tomada de decisão. Revista Organizaçóes em Contexto, 2(4), 92118. Retrieved from http://www.ufrgs.br/gianti/files/ artigos/2007/2007 organizacao em contexto rjm hl hf inteligencia antecipativa coletiva.pdf

Johnston, E. W., \& Hansen, D. L. (2011). Design lessons for smart governance infrastructures. In A. P. Balutis, D. Ink. Transforming American Governance: Rebooting the public square (pp. 197-212). London: Routledge.

Klering, L. R., Porsse, M. C. S., \& Guadagnin, L. A. (2010). Novos Caminhos da Administração Pública Brasileira. Análise, 21(1), 4-17. Retrieved from https:// www.researchgate.net/publication/277097960 Novos Caminhos da Administracao Publica Brasileira

Linders, D., Liao, C. Z. P., \& Wang, C. M. (2015). Proactive e-Governance: Flipping the service delivery model from pull to push in Taiwan. Government Information Quarterly, 35(Supl 4), 68-76. https://doi.org/10.1016/j.giq.2015.08.004

Lindner, F., \& Wald, A. (2011). Success factors of knowledge management in temporary organizations. International Journal of Project Management, 29(7), 877-888. https://doi.org/10.1016/j.ijproman.2010.09.003
Liu, X., \& Zheng, L. (2015). Cross-departmental collaboration in one-stop service center for smart governance in China: Factors, strategies and effectiveness. Government Information Quarterly, 35(Supl4), 54-60. https://doi.org/10.1016/j.giq.2015.12.001

McBride, K., Aavik, G., Kalvet, T., \& Krimmer, R. (2018). Cocreating an open government data driven public service: The case of Chicago's Food inspection forecasting model. https://doi.org/10.24251/HICSS.2018.309

Malomo, F., \& Sena, V. (2017). Data intelligence for local government? Assessing the benefits and barriers to use of big data in the public sector. Policy \& Internet, 9(1), 7-27. https://doi.org/10.1002/poi3.141

Mao, H., Liu, S., Zhang, J., \& Deng, Z. (2016). Information technology resource, knowledge management capability, and competitive advantage: The moderating role of resource commitment. International Journal of Information Management, 36(6), 1062-1074. https://doi.org/10.1016/j.ijinfomgt.2016.07.001

Ministério do Planejamento. (2016). Orçamento e Gestão. Programa GESPÚBLICA, Instrumento para Avaliação da Gestão Pública-250 Pontos. Brasília, DF: Secretaria de Gestão Pública, 2015. Versão 1/2016. Retrieved from http:// www.gespublica.gov.br/sites/default/files/documentos/ gagp-250 pontos novo.pdf

Monavvarian, A., \& Kasaei, M. (2007). A KM model for public administration: The case of Labour Ministry. Vine, 37(3), 348-367. https://doi.org/10.1108/03055720710825654

Myers, M. D. (2013). Qualitative research in business and management. Thousand Oaks, CA: Sage Publications.

Nonaka, I. (1994). A dynamic theory of organizational knowledge creation. Organization Sscience, 5(1), 14-37. Retrieved from www.jstor.org/stable/2635068

Nonaka, I., \& Konno, N. (1998). The concept of "Ba": Building a foundation for knowledge creation. California Management Review, 40(3), 40-54. Retrieved from http://home.business. utah.edu/actme/7410/Nonaka\%201998.pdf

Nonaka, I., \& Takeuchi, H. (2008). Teoria da criação do conhecimento organizacional. In I. Nonaka, H. Takeuchi. Gestáo do conhecimento (pp. 54-90). Porto Alegre: Bookman.

Paula, G., de, \& Rover, A. J. (2012). O governo eletrônico e a atividade de inteligência. Revista Democracia Digital e Governo Eletrônico, 1(6) 216-237. Retrieved from http:// buscalegis.ufsc.br/revistas/index.php/observatoriodoegov/ article/view/89

Paula, A. P. P., de. (2005). Administração pública brasileira entre o gerencialismo e a gestáo social. Revista de Administração de Empresas, 45(1), 36-49. http://dx.doi.org/10.1590/S0034-75902005000100005

Pee, L. G., \& Kankanhalli, A. (2016). Interactions among factors influencing knowledge management in public-sector organizations: A resource-based view. Government Information Quarterly, 33(1), 188-199. https://doi.org/10.1016/j.giq.2015.06.002 
Pereira, L.C.B. (1996). Da administração pública burocrática à gerencial. Revista do Serviço Público, 47(1), 1-28. https://doi.org/10.21874/rsp.v47i1.702

Przeybilovicz, E., Cunha, M.A., Macaya, J. F. M., \& Albuquerque, J. P. D. (2018 January). A Tale of two "Smart Cities": Investigating the echoes of new public management and governance discourses in Smart City Projects in Brazil. Proceedings of the Hawaii International Conference on System Sciences, Honolulu, HI, USA, 51.

Ragin, C. C. (2000). Fuzzy-set social science. Chicago: University of Chicago Press.

Ragin, C. C. (2005). From fuzzy sets to crisp truth tables. Retrieved from http://compasss.org/wpseries/Ragin2004.pdf

Ragin, C. C. (2008). Redesigning social inquiry: Fuzzy sets and beyond. Chicago: University of Chicago Press. https://doi.org/10.7208/chicago/9780226702797.001.0001

Rezende, D. A., \& Frey, K. (2005). Administração estratégica e governança eletrônica na gestão urbana. Revista Eletrônica de Gestão de Negócios, 1(1), 51-59. Retrieved from https:// www.unisantos.br/mestrado/gestao/egesta/artigos/24.pdf

Rezende, D. A. (2012). Projeto de Organizational Business Intelligence (OBI): modelo organizacional de três organizaçóes paranaenses. Anais do CONTECSI Congresso Internacional de Gestão da Tecnologia e Sistemas de Informação, Sáo Paulo, SP, Brazil, 9.

Ribeiro, L. M. D. P., Pereira, J. R., \& Benedicto, G. C. D. (2013). As reformas da administração pública brasileira: Uma contextualização do seu cenário, dos entraves e das novas perspectivas. Anais EnANPAD, Rio de Janeiro, RJ, Brazil, 37.

Riege, A., \& Lindsay, N. (2006). Knowledge management in the public sector: stakeholder partnerships in the public policy development. Journal of knowledge management, 10(3), 24-39. https://doi.org/10.1108/13673270610670830

Rihoux, B. \& Ragin, C. C. (2009). Configurational comparative methods. Qualitative Comparative Analysis (QCA) andrelated techniques. https://dx.doi.org/10.4135/9781452226569

Rios, F. D. C., Strauss, L. M., Janissek-Muniz, R., \& Brodbeck, A. G. (2011). Inteligência competitiva, empresarial, estratégica ou de negócios? Um olhar a partir da Administração de Empresas. Facef Pesquisa, 14(2), 225238. Retrieved from http://periodicos.unifacef.com.br/ index.php/facefpesquisa/article/view/278/269

Schedler, K., Guenduez, A.A., \& Frischknecht, R. (2019). How smart can government be? Exploring barriers to the adoption of smart government. Information Polity, 24(1), 3-20. https://doi.org/10.3233/IP-180095
Scholl, H. J., \& Scholl, M. C. (2014). Smart governance: A roadmap for research and practice. iConference 2014 Proceedings, Illinois, CH, USA. https://doi.org/10.9776/14060

Schutte, N., \& Barkhuizen, N. (2015). Knowledge management and sharing in local government: A social identity theory perspective. Electronic Journal of Knowledge Management, 13(2), 131-142. Retrieved from http://www.ejkm.com/volume13/issue2

Secchi,L.(2009).Modelosorganizacionaisereformasdaadministração pública. Revista de Administração Pública, 43(2), 347-369. https://doi.org/10.1590/S0034-76122009000200004

Shinoda, A. C. M., Maximiano, A. C. A., \& Sbragia, R. (2015). Gestão do conhecimento em organizaçóes orientadas para projetos. Gestão e Projetos: GeP, 6(1), 95-110. http://doi.org/10.5585/gep.v6i1.111

Terra, J. C. C., \& Almeida, C. (2008). Gestão do Conhecimento e Inteligência Competitiva: duas faces da mesma moeda. Terra Fórum Associados. Retrieved from http:// docplayer.com.br/84936701-Gestao-do-conhecimentoe-inteligencia-competitiva-duas-faces-da-mesma-moeda. $\underline{\mathrm{html}}$

Tzortzaki, A. M., \& Mihiotis, A. (2014). A review of knowledge management theory and future directions. Knowledge and Process Management, 21(1), 29-41. https://doi.org/10.1002/kpm.1429

Valle-Cruz, D., \& Sandoval-Almazan, R. (2018, May). Towards an understanding of artificial intelligence in government. Proceedings of the Annual International Conference on Digital Government Research: Governance in the Data Age, Delft, Netherlands, 19. https://doi.org/10.1145/3209281.3209397

Voronchuk, I., \& Starineca, O. (2014). Knowledge management and possibilities of professional development in public sector. European Integration Studies, (8), 168-179. https://doi.org/10.5755/j01.eis.0.8.6844

Weber, R. P. (1990). Quantitative applications in the social sciences: basic content analysis, $2^{\text {nd }}$ ed. Thousand Oaks: Sage.

Welsh, W (2014, June 5). Smart Government: All about disruption. Information Week. https://www.informationweek.com/ government/open-government/smart-government-allabout-disruption/d/d-id/1269459

Wiig, K.M.(1997). Knowledgemanagement: Wheredid itcomefrom and where will it go? Expert Systems With Applications, 13(1), 1-14. https://doi.org/10.1016/S0957-4174(97)00018-3

Wiig, K. M. (2002). Knowledge management in public administration. Journal of Knowledge Management, 6(3), 224-239. https://doi.org/10.1108/13673270210434331 


\section{Authorship}

\section{Claudia Melati*}

Universidade Federal do Rio Grande do Sul, Escola de Administração

Rua Washington Luiz, no 855, Centro Histórico, 90010-460, Porto Alegre, RS, Brazil.

E-mail address: cmelati@yahoo.com.br

(1) https://orcid.org/0000-0002-9369-0113

\section{Raquel Janissek-Muniz}

Universidade Federal do Rio Grande do Sul, Escola de Administração

Rua Washington Luiz, no 855, Centro Histórico, 90010-460, Porto Alegre, RS, Brazil.

E-mail address: rjmuniz@ufrgs.br

(D) https://orcid.org/0000-0002-0657-6559

\section{Carla Maria Marques Curado}

Universidade de Lisboa, Instituto Superior de Economia e Gestão. Rua do Quelhas, no 6, 1200-781, Lisboa, Portugal.

E-mail address: ccurado@iseg.ulisboa.pt

(D) https://orcid.org/0000-0002-2608-8982

* Corresponding Author

\section{Funding}

There are no funders to report for this article.

\section{Conflict of Interests}

The authors have stated that there is no conflict of interest.

\section{Copyrights}

RAC owns the copyright to this content.

\section{Plagiarism Check}

The RAC maintains the practice of submitting all documents approved for publication to the plagiarism check, using specific tools, e.g.: iThenticate.

\section{Authors' Contributions}

$1^{\text {st }}$ author: conceptualization (equal); data curation (leader); formal analysis (equal); investigation (leader); methodology (equal); project administration (equal); supervision (equal); visualization (equal); writing - original draft (leader); writing - review and editing (equal).

$2^{\text {nd }}$ author: conceptualization (equal); data curation (supporting); formal analysis (equal); investigation (supporting); methodology (equal); project administration (equal); supervision (equal); visualization (equal); writing - original draft (supporting); writing - review and editing (equal).

$3^{\text {rd }}$ author: conceptualization (equal); data curation (supporting); formal analysis (equal); investigation (support); methodology (equal); project administration (equal); supervision (equal); visualization (equal); writing - original draft (supporting); writing - review and editing (equal).

\section{Peer Review Method}

This content was evaluated using the double-blind peer review process. The disclosure of the reviewers' information on the first page, as well as the Peer Review Report, is made only after concluding the evaluation process, and with the voluntary consent of the respective reviewers and authors.

\section{Data Availability}

All data and materials were made publicly available through the Mendeley platform and can be accessed at:



Melati, Claudia; Janissek-Muniz, Raquel; Curado, Carla (2020), "Data for: "Decisionmaking quality of public managers: contributions from Intelligence and Knowledge Management" published by RAC - Revista de Administraçáo Contemporânea", Mendeley Data, v3. http://dx.doi.org/10.17632/j4jgpmnp7m.3 